\title{
雨量・水位データと流出モデルを用いた 水位流量曲線作成法の実用性 A METHOD FOR ESTABLISHING STAGE-DISCHARGE CURVE BY USING RAINFALL, WATER LEVEL DATA AND RUNOFF MODEL
}

\author{
田村隆雄 ${ }^{1} \cdot$ 山下瑛人 ${ }^{2} \cdot$ 武藤裕則 $^{3}$ \\ Takao TAMURA, Akito YAMASHITA, and Yasunori MUTO \\ 1正会員 博 (工) 徳島大学 准教授 大学院シ沂ク州任久研究部（７770-8506 徳島市南常三島町2-1） \\ 2学生員 学(工) 徳島大学 大学院先端技術科学教育部 ( $7770-8506$ 徳島市南常三島町2-1)

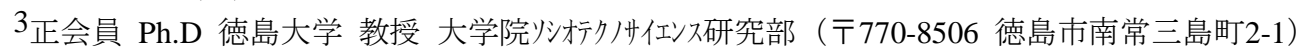

\begin{abstract}
A method for establishing stage-discharge curve ( $H-Q$ curve) using a runoff model to the rainfall observed in a basin and the water level observed in a river channel was discussed. A quadratic function that represented the relation between water level and discharge was built into the runoff model. When the observed water level hydrographs at some floods were reproduced, the $H-Q$ curve was obtained. The method was applied to six water level stations in Shikoku which observed runoff quantity, and the established curve was compared with the $H-Q$ curve based on the runoff observation. Two major findings were obtained: (1) a satisfied $H-Q$ curve in which the error was 5-17\% compared with measurement $H-Q$ curve could be set up by using the data of one main flood event when there was a rain-gauge stations for each $30 \mathrm{~km}^{2}$ in the basin or more; (2) a useful $H-Q$ curve was still obtained by using a lot of flood events when the rain-gauge stations were sparse and were unevenly distributed.
\end{abstract}

Key Words : Stage-discharge curve(H-Q curve), Water budget, Runoff model, Quadratic function

\section{1. はじめに}

流出解析の多くは雨量と流量の観測資料を用いて行わ れる. このうち流量は事前の水位流量観測から作成され た水位一流量曲線（以下， $H$ - $Q$ 曲線）から算出されるの が普通である。一方で国土交通省の水文・水質データ ベースや地方自治体の防災WEBページを見ると流量に 比べ水位の情報量が圧倒的に多い. これは流量観測のコ ストが高いことや防災観点では水位情報で十分な場合が 多いことが理由と考えられる. 著者らはこれらの点に注 目して情報量が豊富な水位情報を用いた流出解析法を提 案し, 流量観測が行われていない中小河川の洪水解析, 例えば平成16年に襲来した複数の台風による徳島・香川 県下の中小河川洪水のハイドログラフの再現1)や，平成 21年9月の佐用洪水のピーク流量の推定 ${ }^{2}$ を行ってきた.

この解析法では流量の推定值が得られるので, 副産物 として水位観測点における $H-Q$ 曲線の作成が可能である. しかし水位流量観測を実施している観測所に本解析法を
適用して，実際に運用されている $H-Q$ 曲線と比較すると いった検証までには至っていなかった。

雨量・水位データを使った流出解析法によって作成さ れる $H-Q$ 曲線の実用性を検証することができれば，蓄積 された膨大な水文データを有効活用して $H-Q$ 曲線を安価 に整備できる．また現時点で水位を観測していない河川 であっても観測点に安価なロガー付き水位計を設置する だけで $H-Q$ 曲線を作成することが可能になることから， 例えば，数が多く管理コストの面でも制約が大きい中小 河川の管理に貢献できる.

以上のような経緯から, 本研究では四国の一級水系に 属する6箇所の水位流量観則所を対象に, 雨量・水位 データを用いた流出解析法を適用して $H-Q$ 曲線を作成す る. この方法で得られる曲線を “モデル $H-Q$ 曲線” と記 す. そして流量観測から作成, 運用されている $H-Q$ 曲線 (以下 “流観 $H-Q$ 曲線” ) と比較して, ほぼ同程度の実 用に耐えうるものが得られるかどうかを考察する. そし て実用性の高いモデル $H-Q$ 曲線を得るための留意点や忘 用性について知見を得る. 


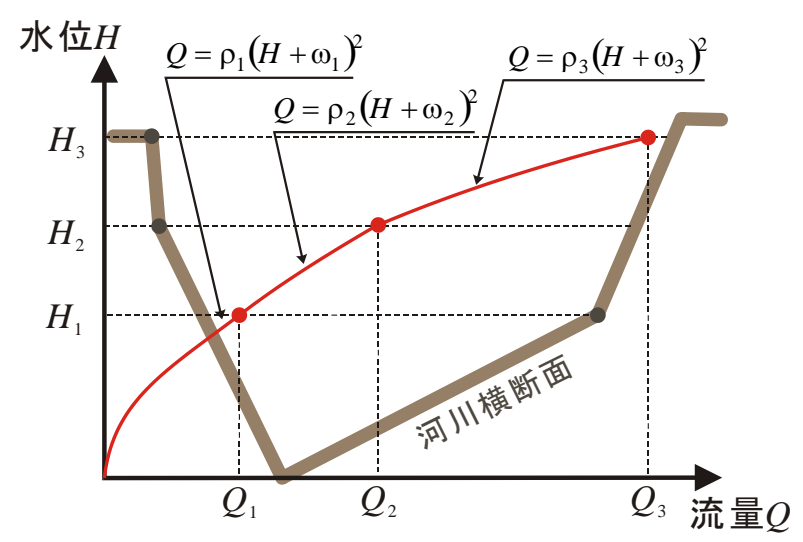

図-1＼cjkstart水位レベルの設定例（区間数：3）

\section{2. 雨量・水位データを用いた流出解析法}

\section{(1) 概要}

雨量・水位データを用いた流出解析法は，任意の流出 モデルに水位・流量変換モデルを組み合わせて, 流域平 均雨量から流量, 流量から水位を計算し, 計算水位八人 ドログラフと観測水位八イドログラフが一致するように モデルの未知パラメータを同定するものである. 本研究 では流出モデルとして地表面流分離直列2段タンクモデ ル3)を使用する．以下ではモデル $H-Q$ 曲線の作成に直接 関わる水位・流量変換モデルと計算法を説明する.

\section{（2） 水位・流量変換モデル}

水位・流量の変換法としてはManning公式を用いた方 法が考えられる る以下のような 2 次関数占を用いる.

$$
Q=\rho(H+\omega)^{2}
$$

ここで $\rho, \omega$ は倸数, $H$ は水位である. 流量 $Q$ は水位 $H$ とそれに対応する $\rho$ と $\omega$ の関数であって, ある $H$ に対して $1 つ の ~ Q$ が決まる水位流量と仮定寸る.

モデルの適用にあたっては，図-1に示すように，まず 観測地点の $H-Q$ 関係を表せるよう, 河道横断面形状を参 考にして水位レベルを適当な数だけ設定し，区間 $(i-1 \sim i)$ 毎に式(2)を設定する.

$$
Q_{i}=\rho_{i}\left(H_{i}+\omega_{i}\right)^{2}
$$

ここで $Q_{i}$ は事前に設定した水位レベル $H_{i}$ に対応する水 位流量で未知パラメータ， $\rho_{i}$ と $\omega_{i}$ は区間 $(i-1 \sim i)$ の係数で未知パラメータである.

次に全区間の $H-Q$ 式を繋げる．まず式(2)に $H_{1}$ とそれ に対応する $Q_{1}$ および $\omega_{1}$ を代入して $\rho_{1}$ を決定する. 次に $Q_{1}$ と $H_{1}, Q_{2}$ と $H_{2}$ が $Q_{i}=\rho_{2}\left(H_{i}+\omega_{2}\right)^{2}$ の下限と上 限であることから，これに代入して比をとると，次のよ うに $\omega_{2}$ が定まり，次いで $\rho_{2}$ も決定できる.

\begin{tabular}{|c|c|c|c|c|}
\hline 観測所名 & $\begin{array}{l}\text { 水系 · } \\
\text { 河川名 }\end{array}$ & 流域面積 & $\begin{array}{l}\mathrm{H}-\mathrm{Q} \text { 曲線 } \\
\text { 作成年月 }\end{array}$ & $\begin{array}{c}\text { 雨量計 } \\
\text { の数 }\end{array}$ \\
\hline $\begin{array}{l}\text { み上らごん } \\
\text { 明神 }\end{array}$ & $\begin{array}{c}\text { 土器川· } \\
\text { 土器川 }\end{array}$ & $37 \mathrm{~km}^{2}$ & 2007年8月 & 2 \\
\hline $\begin{array}{l}\text { 拉もでか } \\
\text { 表川 }\end{array}$ & $\begin{array}{l}\text { 重信川・・ } \\
\text { 表川 }\end{array}$ & $66 \mathrm{~km}^{2}$ & 2007年7月 & 3 \\
\hline $\begin{array}{l}\text { 勍んま } \\
\text { 明間 }\end{array}$ & $\begin{array}{l}\text { 肱川 } \\
\text { 肱川 }\end{array}$ & $105 \mathrm{~km}^{2}$ & 2007年6月 & 3 \\
\hline $\begin{array}{l}\text { 瑯か刃 } \\
\text { 池川 }\end{array}$ & $\begin{array}{c}\text { 仁淀川・ } \\
\text { 土居川 }\end{array}$ & $130 \mathrm{~km}^{2}$ & 2007年8月 & 4 \\
\hline $\begin{array}{l}\text { しもやかわ } \\
\text { 下八川 }\end{array}$ & $\begin{array}{l}\text { 仁淀川 } \\
\text { 上八川川 }\end{array}$ & $160 \mathrm{~km}^{2}$ & 2007年8月 & 5 \\
\hline $\begin{array}{l}\text { くりのき } \\
\text { 栗ノ木 }\end{array}$ & $\begin{array}{c}\text { 四万十川・ } \\
\text { 四万十川 }\end{array}$ & $165 \mathrm{~km}^{2}$ & 2009年8月 & 1 \\
\hline
\end{tabular}

表-1 水位流量観測所流域の概要

$$
\begin{aligned}
& \omega_{2}=\left(H_{2} \sqrt{Q_{1} / Q_{2}}-H_{1}\right) /\left(1-\sqrt{Q_{1} / Q_{2}}\right) \\
& \rho_{2}=Q_{1} /\left(H_{1}+\omega_{2}\right)^{2}
\end{aligned}
$$

これで河床から水位レベル $H_{2}$ までの仮 $H-Q$ 曲線がで きる.この作業を設定した区間数だけ繰り返すと観測点 の仮 $H-Q$ 曲線ができあがる. 同定すべき未知パラメー 夕は各水位レベルに対応する水位流量 $Q_{i}$ と $\omega_{1}$ である.

最後にパラメータ同定であるが，まず観測雨量を流出 モデルに入力して流量を試算する。この試算流量を水 位・流量変換モデルに入力して仮 $H-Q$ 曲線から水位を計 算する. そして解析期間内の計算水位と観測水位との誤 差を最小とするような流出モデルと水位・流量モデルの 最適パラメータ組を求める. 最適パラメータ組による仮 $H-Q$ 曲線は実際の水位・流量関係を表現できるものとし てモデル $H-Q$ 曲線として採用する.

\section{（3） 使用する水文データと計算方法}

使用する水文デー夕は国土交通省水文・水質デー夕 ベースより時間データを入手した．モデルに入力する流 域平均雨量はティーセン分割法を用いて計算し, 遮断モ デル3゙用いて得られる地表面到達雨量を使用した。 パ ラメータ同定は洪水期間中の観測水位ハイドログラフと 計算水位八イドログラフの誤差二乗和の平均值が最小と なるようにシンプレックス法を用いて探索した。

\section{3. 対象とした水位流量観測所と洪水イベント}

\section{（1） 水位流量観測所}

モデル $H-Q$ 曲線の実用性を考察するため，流域内外の 雨量観測所の数や配置が異なる $6 \supset$ 水位流量観測所を 選定した。いずれも四国の一級水系に属する国土交通省 所管の観測所である。それら観測所の諸元を表-1に，雨 量観測所の配置を図-2に示す．観測所の $H-Q$ 曲線は定期 的に見直されているが，本研究では2007年から2009年に 作成された $H-Q$ 曲線を流観 $H-Q$ 曲線とした. 雨量計は図 

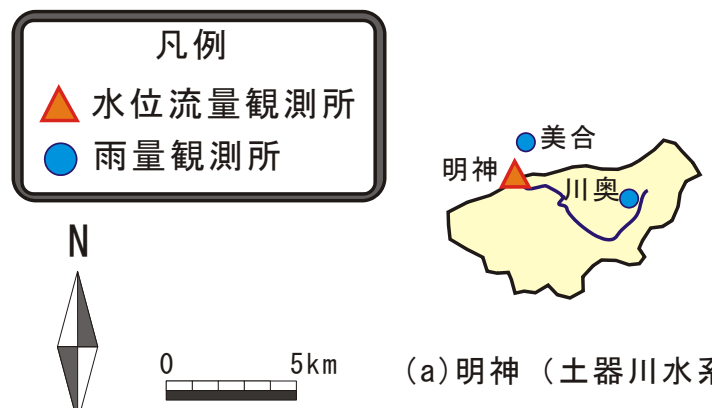

(a)明神 (土器川水系)

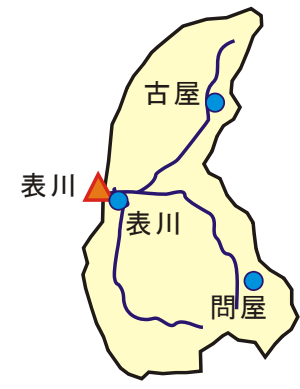

（b）表川（重信川水系）

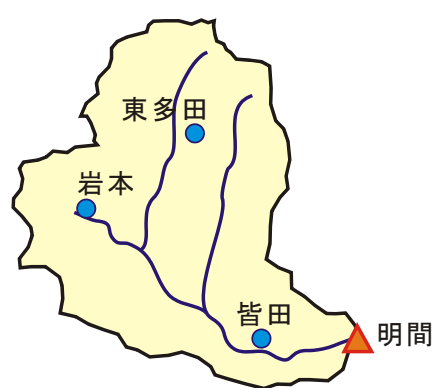

(c)明間（肱川水系）

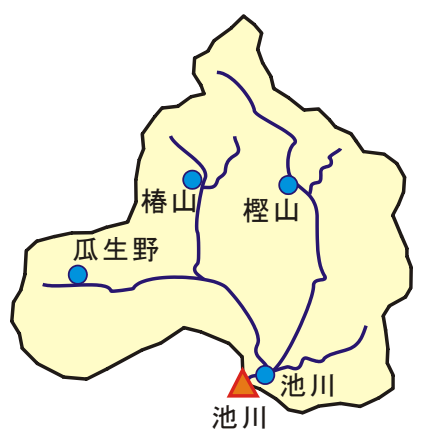

（d）池川（仁淀川水系）

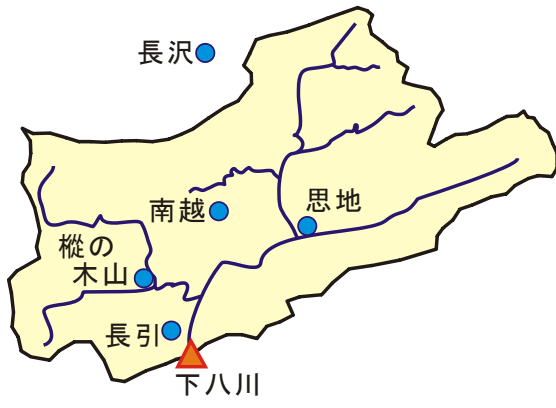

（e）下八川（仁淀川水系）

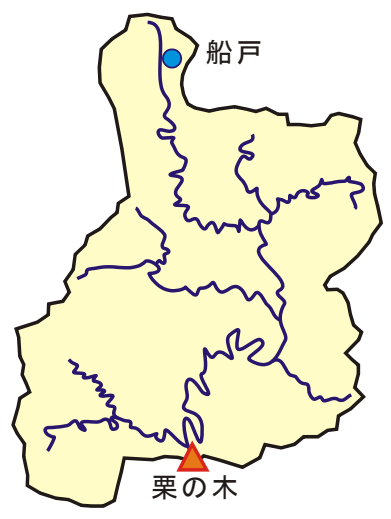

(f) 栗の木（四万十川水系）

図-2 観測所流域内の雨量観測所の配置

中に示した以外にも存在するが，洪水イベントで久測等 があって計算に使用しなかった観測所は記していない. 雨量観測所密度は明神観測所流域と表川観測所流域が高 く，栗ノ木観測所流域が最も低い状況であった。一般的 に雨量観測所密度が高いほど正確な流域平均雨量を計算 できの，流観 $H-Q$ に近いモデル $H-Q$ 曲線ができると考える.

\section{（2） 洪水イベント}

モデル $H-Q$ 曲線作成のために使用する洪水イベントは 各観測所において近年観測されたもののうち，最高水位 が第1位のものを採用して, 高水位までカバーできる $H$ $Q$ 曲線を作成する. 表-2に使用する洪水イベントを示す 洪水イベントあるいは流域によっては，雨量観測所の密 度や配置の影響を受けて正確な水収支に支障をきたす場 合もあると考え, 流観 $H-Q$ 曲線とモデル $H-Q$ 曲線が大き く乘離する場合には，使用する洪水イベントを複数にし て再計算する. 雨量観測所の密度や配置に欠点があって 流域平均雨量の精度が特定の洪水イベントでは低くても, 洪水イベントの数を増やすことによって向上すると予想 し, 流観 $H-Q$ 曲線に近いものになると考える.

\section{4. 解析結果と考察}

\section{（1） 1洪水イベントを使って得られたモデルH-Q曲線}

図-3に対象流域6箇所の結果を示寸。上から明神，表 川, 明間, 池川, 下八川, そして栗ノ木で, 左列に流域 平均ハイエトグラフ, 洪水水位ハイドログラフの観測值
表-2 モデルH-Q曲線作成に使用した洪水イベント

\begin{tabular}{|c|c|c|c|c|}
\hline 観測所名 & $\begin{array}{l}\text { 洪水 } \\
\text { 期間 }\end{array}$ & $\begin{array}{l}\text { 総降 } \\
\text { 水量 }\end{array}$ & $\begin{array}{l}\text { 最大降 } \\
\text { 雨強度 }\end{array}$ & $\begin{array}{l}\text { 最高 } \\
\text { 水位 }\end{array}$ \\
\hline $\begin{array}{l}\text { 㔔らじん } \\
\text { 明神 }\end{array}$ & $\begin{array}{l}2005 / 9 / 4- \\
2005 / 9 / 7\end{array}$ & $285 \mathrm{~mm}$ & $23 \mathrm{~mm} / \mathrm{hr}$ & $3.35 \mathrm{~m}$ \\
\hline 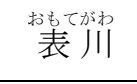 & $\begin{array}{c}2004 / 9 / 27- \\
2004 / 9 / 30\end{array}$ & $170 \mathrm{~mm}$ & $32 \mathrm{~mm} / \mathrm{hr}$ & $3.40 \mathrm{~m}$ \\
\hline $\begin{array}{l}\text { 䐺汃青 } \\
\text { 間 }\end{array}$ & $\begin{array}{c}2004 / 10 / 18- \\
2004 / 10 / 21\end{array}$ & $211 \mathrm{~mm}$ & $23 \mathrm{~mm} / \mathrm{hr}$ & $3.50 \mathrm{~m}$ \\
\hline 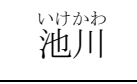 & $\begin{array}{l}2005 / 9 / 4- \\
2005 / 9 / 7\end{array}$ & $841 \mathrm{~mm}$ & $42 \mathrm{~mm} / \mathrm{hr}$ & $7.31 \mathrm{~m}$ \\
\hline $\begin{array}{l}\text { しもやかわ } \\
\text { 下八川 }\end{array}$ & $\begin{array}{c}2004 / 10 / 18- \\
2004 / 10 / 21\end{array}$ & $423 \mathrm{~mm}$ & $66 \mathrm{~mm} / \mathrm{hr}$ & $7.23 \mathrm{~m}$ \\
\hline 栗ノの羑 & $\begin{array}{l}2004 / 10 / 18- \\
2004 / 10 / 21\end{array}$ & $609 \mathrm{~mm}$ & $81 \mathrm{~mm} / \mathrm{hr}$ & $8.95 \mathrm{~m}$ \\
\hline
\end{tabular}

とモデル再現值を示し, 右列に流観 $H-Q$ 曲線とモデル $H$ $Q$ 曲線の比較を示している. 流観 $H-Q$ 曲線が水位の低い 箇所で切れているのは，流量観測を行った洪水イベント とモデル $H-Q$ 曲線の作成に用いた洪水イベントが異なる ことが主な理由である. 左列の水位八イドログラフの再 現結果を見ると，どの観測所も誤差は認められるものの， ピーク水位と全体的な波形は良好に再現できていると判 断する.

表-3に各観測所の水位区間毎のモデル $H-Q$ 曲線を示寸. 例えば区間 1 は河床から水位レベル $H_{1}$ までの区間であり， その区間に適用されるモデル $H-Q$ 曲線と水位レベル $H_{1}$, それに対応寸る流量 $Q_{1}$ が示されている. 本研究で設けた 


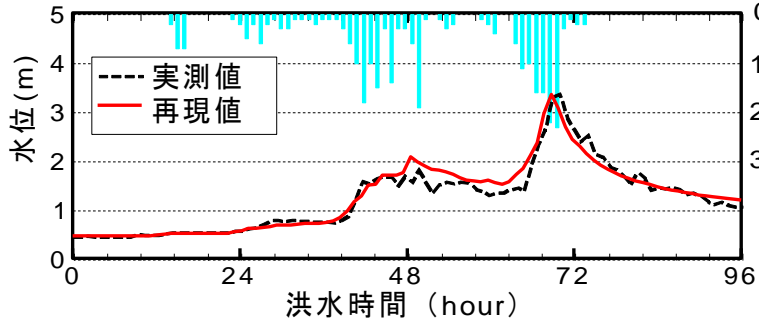

(a) 水位ハイドログラフの再現結果（明神）

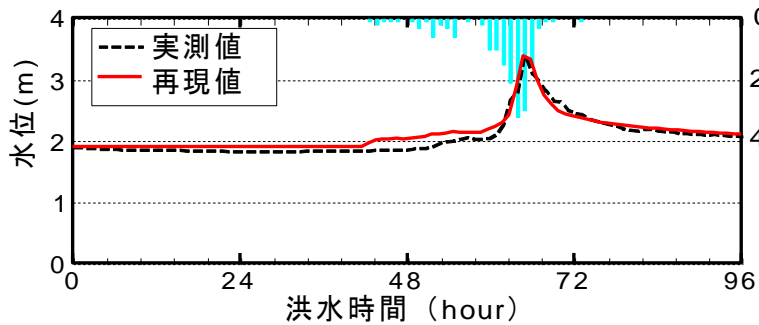

(c) 水位ハイドログラフの再現結果（表川）

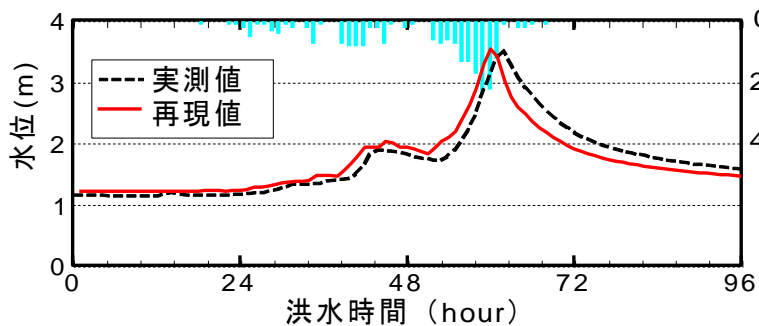

(e) 水位ハイドログラフの再現結果（明間）

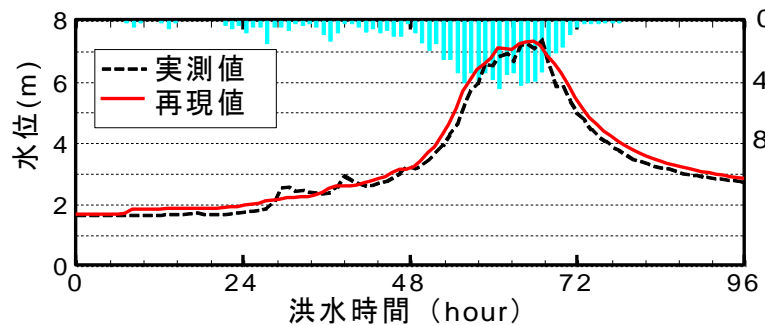

(g) 水位ハイドログラフの再現結果（池川）

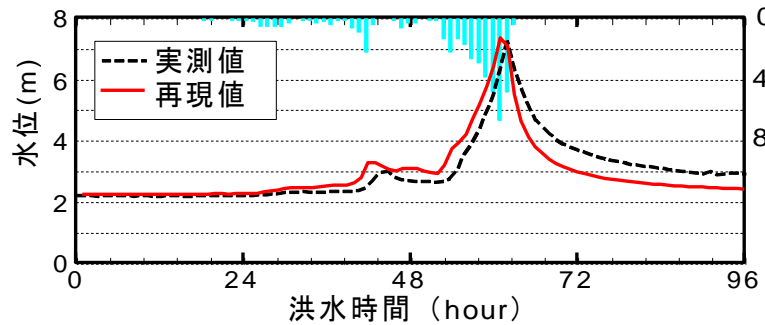

(i) 水位ハイドログラフの再現結果（下八川）

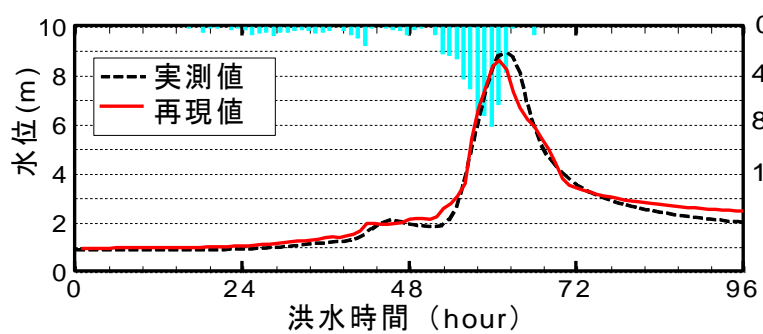

(k) 水位ハイドログラフの再現結果（栗ノ木）

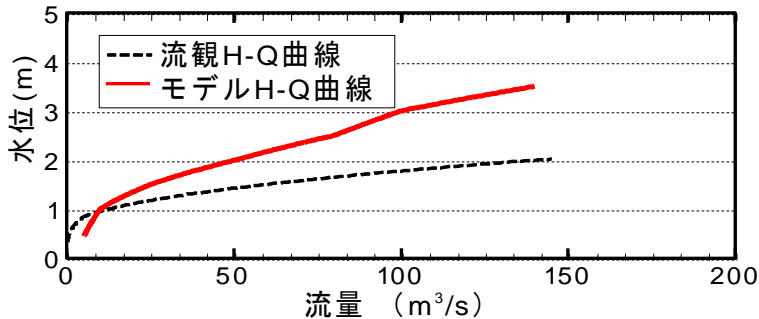

(b) $H-Q$ 曲線の推定結果（明神）

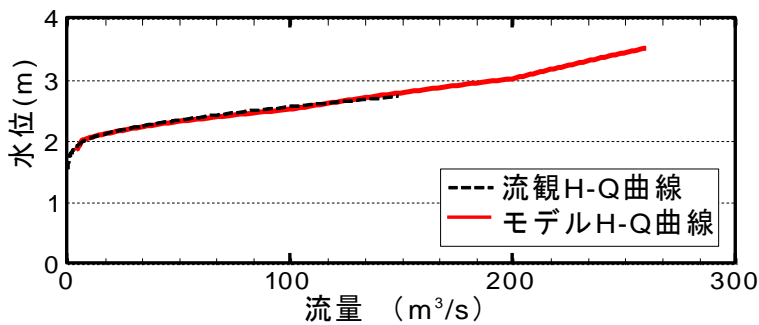

(d) $H-Q$ 曲線の推定結果（表川）

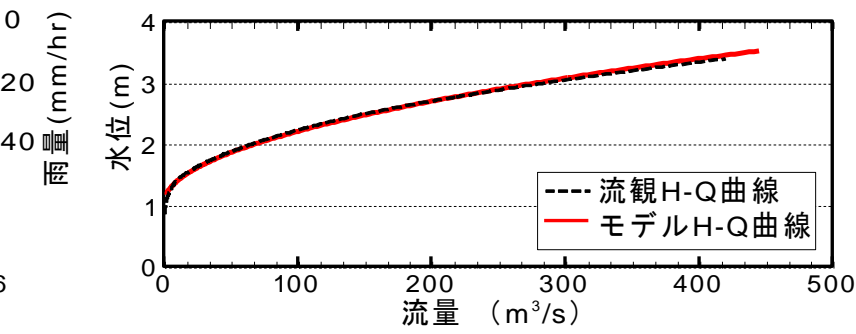

(f) $H-Q$ 曲線の推定結果（明間）

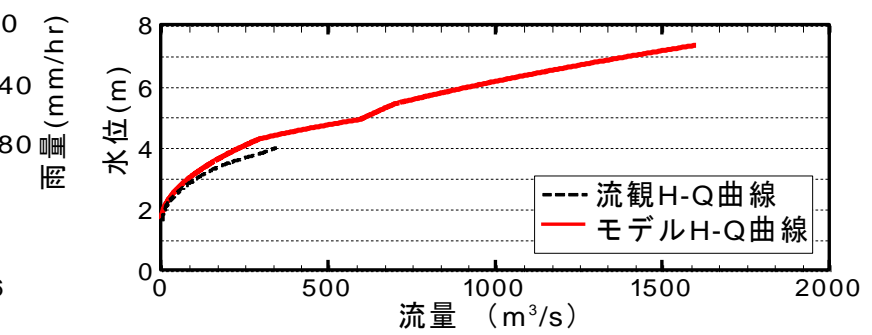

(h) $H-Q$ 曲線の推定結果（池川）

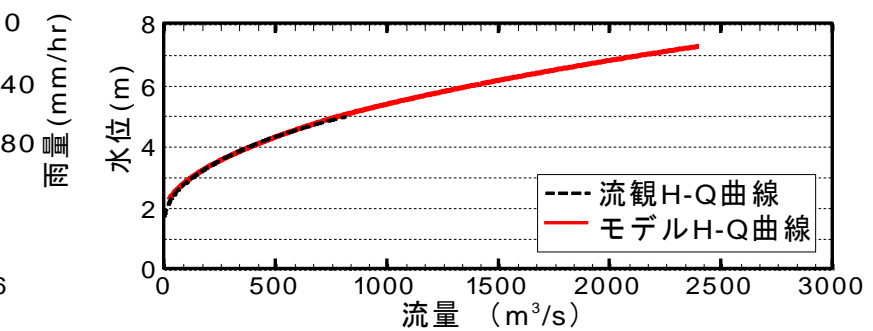

(j) $H-Q$ 曲線の推定結果（下八川）

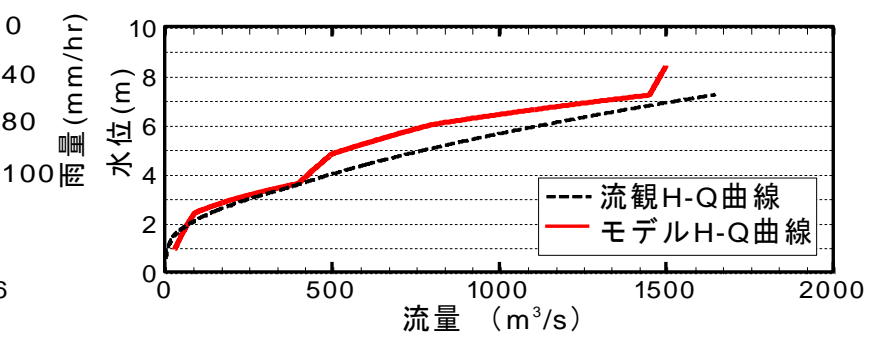

(I) $H-Q$ 曲線の推定結果（栗ノ木）

図-3＼cjkstart水位ハイドログラフの再現およびモデルH-Q曲線と流観 $\mathrm{H}-\mathrm{Q}$ 曲線の比較 
表-3 1洪水イベントを使って作成したモデルH-Q曲線

\begin{tabular}{|c|c|c|c|c|c|c|}
\hline $\begin{array}{l}\text { 水位 } \\
\text { 区間 }\end{array}$ & 盟神 & 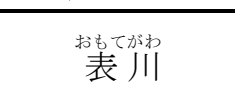 & 腤朚間 & 池川 & 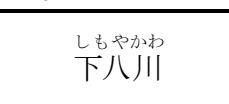 & 栗ノの羑 \\
\hline 1 & $\begin{array}{c}Q=2.63(H+0.95)^{2} \\
H_{1}=1.0 \mathrm{~m} \\
Q_{1}=10.0 \mathrm{~m}^{3} / \mathrm{s}\end{array}$ & $\begin{array}{c}Q=0.045(H+0.98)^{2} \\
H_{1}=0.5 \mathrm{~m} \\
Q_{1}=0.1 \mathrm{~m}^{3} / \mathrm{s}\end{array}$ & $\begin{array}{c}Q=1.47(H+0.1)^{2} \\
H_{1}=1.2 \mathrm{~m} \\
Q_{1}=2.5 \mathrm{~m}^{3} / \mathrm{s}\end{array}$ & $\begin{array}{c}Q=0.43(H+0.9)^{2} \\
H_{1}=1.8 \mathrm{~m} \\
Q_{1}=3.14 \mathrm{~m}^{3} / \mathrm{s}\end{array}$ & $\begin{array}{c}Q=0.30(H+0.3)^{2} \\
H_{1}=1.8 \mathrm{~m} \\
Q_{1}=1.34 \mathrm{~m}^{3} / \mathrm{s}\end{array}$ & $\begin{array}{c}Q=9.07(H+0.9)^{2} \\
H_{1}=1.2 \mathrm{~m} \\
Q_{1}=40 \mathrm{~m}^{3} / \mathrm{s}\end{array}$ \\
\hline 2 & $\begin{array}{c}Q=13.51(H-0.14)^{2} \\
H_{2}=1.5 \mathrm{~m} \\
Q_{2}=25.0 \mathrm{~m}^{3} / \mathrm{s}\end{array}$ & $\begin{array}{c}Q=0.61(H-0.095)^{2} \\
H_{2}=1.0 \mathrm{~m} \\
Q_{2}=0.5 \mathrm{~m}^{3} / \mathrm{s}\end{array}$ & $\begin{array}{c}Q=71.36(H-1.01)^{2} \\
H_{1}=3.6 \mathrm{~m} \\
Q_{1}=445 \mathrm{~m}^{3} / \mathrm{s}\end{array}$ & $\begin{array}{c}Q=39(H-1.516)^{2} \\
H_{2}=4.3 \mathrm{~m} \\
Q_{2}=300 \mathrm{~m}^{3} / \mathrm{s}\end{array}$ & $\begin{array}{c}Q=68.89(H-1.66)^{2} \\
H_{2}=4.15 \mathrm{~m} \\
Q_{2}=427 \mathrm{~m}^{3} / \mathrm{s}\end{array}$ & $\begin{array}{c}Q=6.94(H+1.2)^{2} \\
H_{2}=2.4 \mathrm{~m} \\
Q_{2}=90 \mathrm{~m}^{3} / \mathrm{s}\end{array}$ \\
\hline 3 & $\begin{array}{c}Q=17.75(H-0.31)^{2} \\
H_{3}=2.0 \mathrm{~m} \\
Q_{3}=50.5 \mathrm{~m}^{3} / \mathrm{s}\end{array}$ & $\begin{array}{c}Q=0.34(H-0.207)^{2} \\
H_{3}=1.5 \mathrm{~m} \\
Q_{3}=1.0 \mathrm{~m}^{3} / \mathrm{s}\end{array}$ & & $\begin{array}{c}Q=129.6(H-2.76)^{2} \\
H_{3}=4.9 \mathrm{~m} \\
Q_{3}=4.9 \mathrm{~m}^{3} / \mathrm{s}\end{array}$ & $\begin{array}{c}Q=86.14(H-1.92)^{2} \\
H_{3}=4.95 \mathrm{~m} \\
Q_{3}=789 \mathrm{~m}^{3} / \mathrm{s}\end{array}$ & $\begin{array}{c}Q=76.75(H-1.32)^{2} \\
H_{3}=3.6 \mathrm{~m} \\
Q_{3}=400 \mathrm{~m}^{3} / \mathrm{s}\end{array}$ \\
\hline 4 & $\begin{array}{c}Q=13.51(H-0.07)^{2} \\
H_{4}=2.5 \mathrm{~m} \\
Q_{4}=80.0 \mathrm{~m}^{3} / \mathrm{s}\end{array}$ & $\begin{array}{c}Q=10.8(H-1.196)^{2} \\
H_{4}=2.0 \mathrm{~m} \\
Q_{4}=7.0 \mathrm{~m}^{3} / \mathrm{s}\end{array}$ & & $\begin{array}{c}Q=16.04(H+1.19)^{2} \\
H_{4}=5.4 \mathrm{~m} \\
Q_{4}=700 \mathrm{~m}^{3} / \mathrm{s}\end{array}$ & $\begin{array}{c}Q=83.3(H-1.87)^{2} \\
H_{4}=7.24 \mathrm{~m} \\
Q_{4}=2400 \mathrm{~m}^{3} / \mathrm{s}\end{array}$ & $\begin{array}{c}Q=3.87(H+6.57)^{2} \\
H_{4}=4.8 \mathrm{~m} \\
Q_{4}=500 \mathrm{~m}^{3} / \mathrm{s}\end{array}$ \\
\hline 5 & $\begin{array}{c}Q=4.46(H+1.74)^{2} \\
H_{5}=3.0 \mathrm{~m} \\
Q_{5}=120 \mathrm{~m}^{3} / \mathrm{s}\end{array}$ & $\begin{array}{c}Q=216(H-1.82)^{2} \\
H_{5}=2.5 \mathrm{~m} \\
Q_{5}=100 \mathrm{~m}^{3} / \mathrm{s}\end{array}$ & & $\begin{array}{c}Q=50.27(H-1.67)^{2} \\
H_{5}=7.32 \mathrm{~m} \\
Q_{5}=1600 \mathrm{~m}^{3} / \mathrm{s}\end{array}$ & & $\begin{array}{c}Q=24.37(H-0.27)^{2} \\
H_{5}=6.0 \mathrm{~m} \\
Q_{5}=800 \mathrm{~m}^{3} / \mathrm{s}\end{array}$ \\
\hline 6 & $\begin{array}{c}Q=13.43(H-0.27)^{2} \\
H_{6}=3.5 \mathrm{~m} \\
Q_{6}=140 \mathrm{~m}^{3} / \mathrm{s}\end{array}$ & $\begin{array}{c}Q=68.6(H-1.29)^{2} \\
H_{6}=3.0 \mathrm{~m} \\
Q_{6}=200 \mathrm{~m}^{3} / \mathrm{s}\end{array}$ & & & & $\begin{array}{c}Q=66.62(H-2.53)^{2} \\
H_{6}=7.2 \mathrm{~m} \\
Q_{6}=1450 \mathrm{~m}^{3} / \mathrm{s}\end{array}$ \\
\hline 7 & & $\begin{array}{c}Q=15.7(H+0.567)^{2} \\
H_{7}=3.5 \mathrm{~m} \\
Q_{7}=260 \mathrm{~m}^{3} / \mathrm{s} \\
\end{array}$ & & & & $\begin{array}{c}Q=0.294(H+62.99)^{2} \\
H_{7}=8.4 \mathrm{~m} \\
Q_{7}=1500 \mathrm{~m}^{3} / \mathrm{s}\end{array}$ \\
\hline
\end{tabular}

水位レベルの数は明神が 6 , 池川が 5 , 明間が 2 , 下八川 が4，表川が7，栗ノ木が7であった。概して流域面積が 大きく観測所位置の河道横断面形状が単純なほど水位レ ベルの設定数が少なくて済む傾向にある.

図-3右列の $H-Q$ 曲線を見ると，表川，明間，池川，下 八川ではモデル $H-Q$ 曲線が流観 $H-Q$ 曲線にほぼ合致した. 2 種類の $H-Q$ 曲線の流量誤差の平均は，表川 $16 \%$, 明間 9\%，池川17\%，下八川5\%であった．大きな出水前後で $H-Q$ 関係が変化することがあることや， 2 種類の $H-Q$ 曲線 が異なる洪水イベントから作成されている点，浮子によ る流量観測や $H-Q$ 曲線の精度7), 8), 9)な゙を考えれば，この4 力所では流観 $H-Q$ 曲線に遜色ないモデル $H-Q$ 曲線が得ら れたと考える. 一方, 栗ノ木と明神のモデル $H-Q$ 曲線は 流観 $H-Q$ 曲線と全く異なる結果となった.

\section{（2）複数の洪水イベントを使った場合のモデルH-Q曲線}

洪水イベントを洪水中の最高水位で降順に並べ，上位 3イベントと上位5イベントを用いて明神観測所と栗ノ木 観測所の再計算を行った. 使用した洪水イベントを表-4, 結果を図-4に示す．まず明神のモデル $H-Q$ 曲線では，高 水位区間での変化が若干見られるが，低水位では全く変 化しなかった。 そこで流観 $H-Q$ 曲線の作成に使用された 2009年8月の洪水イベント（表-4の明神観測所順位3の洪 水）の水収支を流観 $H-Q$ 曲線加ら計算寸ると, 総降水量 $154 \mathrm{~mm}$ に対して洪水期間中の流出高 $221 \mathrm{~mm}$ と流出超過 (約1.4倍) となり，流観 $H$-Q曲線の不具合が考えられた。 図-5に水位観測点の河道横断面を示すが，明神観測所は 川幅が狭く大岩が多数不規則に露出していることから，
表-4 追加計算で用いた洪水イベント

\begin{tabular}{|c|c|c|c|c|c|c|}
\hline \multirow{2}{*}{$\begin{array}{l}\text { 順 } \\
\text { 位 }\end{array}$} & \multicolumn{3}{|c|}{ 明神観測所 } & \multicolumn{3}{|c|}{ 栗ノ木観測所 } \\
\hline & $\begin{array}{l}\text { 最高 } \\
\text { 水位 }\end{array}$ & 総雨量 & $\begin{array}{l}\text { 洪水 } \\
\text { 年月 }\end{array}$ & $\begin{array}{l}\text { 最高 } \\
\text { 水位 }\end{array}$ & 総雨量 & $\begin{array}{l}\text { 洪水 } \\
\text { 年月 }\end{array}$ \\
\hline 1 & $3.35 \mathrm{~m}$ & $285 \mathrm{~mm}$ & $2005 / 9$ & $8.95 \mathrm{~m}$ & $609 \mathrm{~mm}$ & $2004 / 10$ \\
\hline 2 & $3.30 \mathrm{~m}$ & $125 \mathrm{~mm}$ & $2004 / 9$ & $8.14 \mathrm{~m}$ & $968 \mathrm{~mm}$ & $2005 / 9$ \\
\hline 3 & $2.05 \mathrm{~m}$ & $154 \mathrm{~mm}$ & $2009 / 8$ & $7.06 \mathrm{~m}$ & $366 \mathrm{~mm}$ & $2004 / 8$ \\
\hline 4 & $1.95 \mathrm{~m}$ & $120 \mathrm{~mm}$ & $2004 / 8$ & $6.98 \mathrm{~m}$ & $519 \mathrm{~mm}$ & $2004 / 6$ \\
\hline 5 & $1.50 \mathrm{~m}$ & $101 \mathrm{~mm}$ & $2010 / 6$ & $4.84 \mathrm{~m}$ & $585 \mathrm{~mm}$ & $2006 / 8$ \\
\hline
\end{tabular}

洪水時の正確な流量観測は困難が伴うと想像される.

次に栗ノ木であるが，水位 $3.6 \mathrm{~m} \sim 6.0 \mathrm{~m}$ で顕著な改善が 見られる。この区間における流観流量に対寸る誤差の割 合の平均は1洪水で $25 \% ， 3$ 洪水で $21 \% ， 5$ 洪水では $11 \%$ と 洪水イベント数を増やすほどモデル $H-Q$ 曲線が流観 $H-Q$ 曲線に近づいた。 ただし水位 $2.4 \mathrm{~m} 〜 3.6 \mathrm{~m}$ の間では流観 $H$-Q曲線と乘離したほか，水位7.2m以上の区間では全く 改善できていない，前者の原因は不明であるが，後者に ついてはこの水位区間が上位 $2 つ の$ 洪水イベントでしか カバーできない事が原因と考える. 栗ノ木のように水収 支計算に雨量観測所の数や配置の影響が大きいと考えら れる場所では，洪水イベントを増やして計算することで 流観 $H-Q$ 曲線に遜色ないものが得られる見込みがある.

\section{5. 結論}

雨量・水位データと流出モデルを使用した水位一流量 


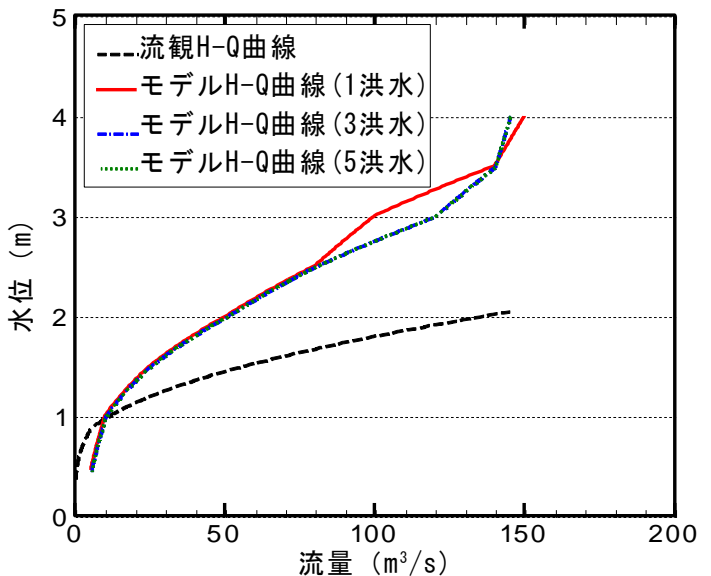

(a) $H-Q$ 曲線の推定結果（明神）

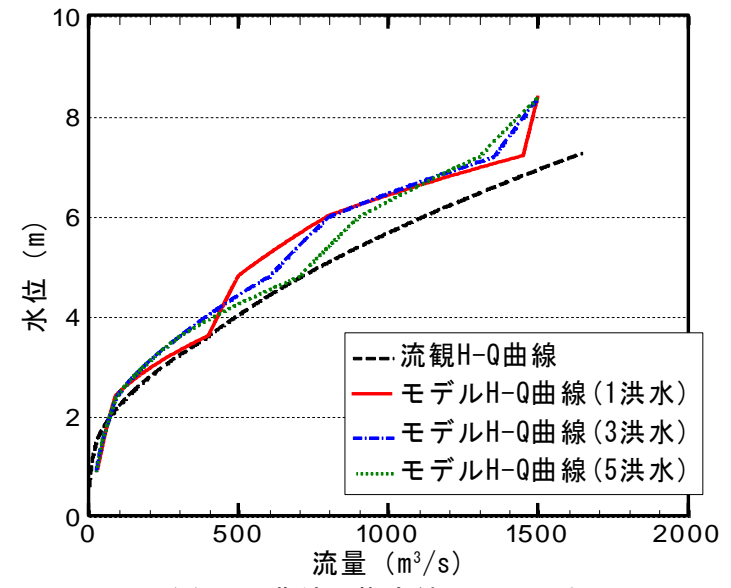

(b) $\mathrm{H}-\mathrm{Q}$ 曲線の推定結果（栗ノ木）

\section{図-4 複数の洪水イベントを使って作成したモデルH-Q曲線}

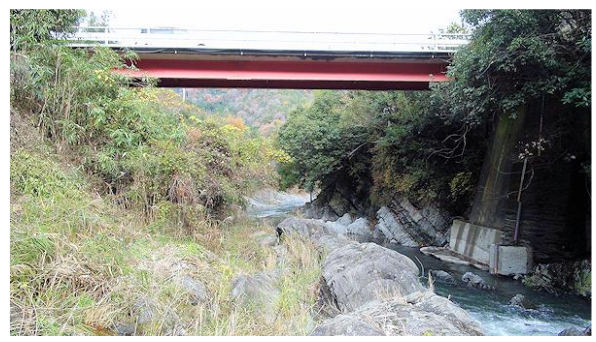

(a) 明神観測点

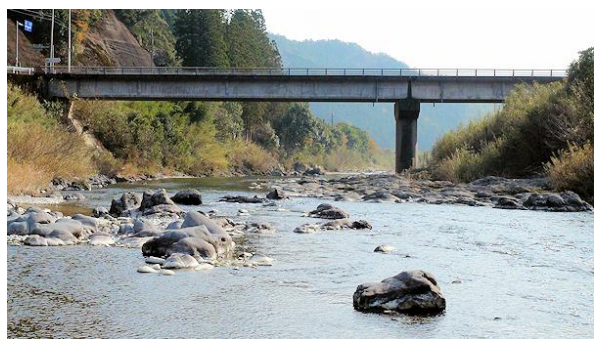

(b) 栗ノ木観測点

図-5 水位流量観測所の河道横断面 （明神，栗ノ木 いずれも上流から望む）

曲線作成法の実用性について6箇所の水位流量観測所流 域を対象に考察を行い，次のような知見を得た.

(1) 観測所流域の水収支を良好に計算できる雨量観測 所の数と配置であれば, 1 つの大きな洪水イベン 卜を使って流観 $H-Q$ 曲線と同程度のモデル $H-Q$ 曲 線を作成することができる.

(2) 雨量観測所の数や偏在が水収支計算に大きな影響 を及ぼすと考えられる場合，モデル $H-Q$ 曲線の精 度を高める1つの手段として使用する洪水イベン

卜数を増やすことが有効だと考えられる.

また雨量計の密度が低い栗ノ木観測所流域と流量観測 点の河道横断面が複雑な形状を呈している明神観測所流 域における議論から, 次のようなモデル $H-Q$ 曲線の応用 が考えられた。

(1) 水収支という視点からの流観 $H-Q$ 曲線の検証.

(2) 流域の水文データの品質向上や観測の効率化に関
する検討. 例えば雨量観測所の数や配置, 流量観 測における浮子形式の選定や測線数などの検討. その他，流観 $H-Q$ 曲線が整備されていない高水位区間 の外挿等にも応用できると考えられる. 今後はさらにモ デル $H-Q$ 曲線の特徵や適用に関する知見を集積し一般化 を目指したい。 また $H-Q$ 曲線が未整備の山地河川や中小 河川での洪水流量評価などにも活用したいと考えている.

謝辞 : 本研究では国土交通省四国地方整備局から $H-Q$ 曲 線の資料提供を受けました。 また平成24年度科学研究費 補助金（基盤研究(C), 課題番号24560624）の補助を受 けました。ここに謝意を表します。

\section{参考文献}

1）田村隆雄，端野道夫，橘大樹：一般中小河川にも適用可能 な雨量・水位データを用いた流出解析モデルパラメータの同 定手法，水工学論文集，50，pp.350-355，2006.

2) 田村隆雄, 中内章浩, 小川健一郎 : 平成21年9月佐用水害の 洪水ピーク流量の推定と流出特性に関する考察，水工学論文 集, 55, pp.559-564, 2011.

3) 端野道夫, 田村隆雄, 田淵昌之, 冨士川洋一: 森林流域に おける遮断蒸発・蒸散量と流域地中保水量の分離・評価法, 水工学論文集, 48, pp.31-36, 2004.

4) 田村隆雄, 端野道夫, 橘大樹 : 雨量・水位データを使用し たH-Q曲線の作成方法，土木学会四国支部平成18年度自然災 害フォーラム論文集，pp.1-8，2006.

5) 社団法人日本河川協会編 : 改訂新版建設省河川砂防技術基 隻(案)同解説 調査編，p.52，技報堂，1997.

6) 川畑幸夫編著 : 水文気象学2版，pp.64-67，地人書館， 1967.

7) 土木学会 : 水理公式集 [平成11年度版], pp.75-86, 丸善, 1999.

8) 山口高志 : 洪水流速および流量観測一その 1 -, 水文・水 資源学会誌，Vol.15, No.6, pp.625-635, 2002.

9) 独立行政法人土木研究所編著: 平成14年度版水文観測, pp.132-157, 社団法人全日本建設技術協会, 2002.

(2012. 9. 30受付) 